\title{
The Effect of Human Resource Management Practices on MNC Subsidiary Performance in Russia
}

\author{
by \\ CARL F. FEY \\ Stockholm School of Economics \\ P.O. Box 6501 \\ S-11383 Stockholm, Sweden \\ Tel. (46-8)-736-9501 \\ Fax. (46-8)-31-9927 \\ E-Mail: iibcf@hhs.se \\ and
}

Stockholm School of Economics in St. Petersburg

\author{
INGMAR BJÖRKMAN \\ Swedish School of Economics \\ Post Box 479, 00101 Helsinki, Finland \\ E-Mail: ingmar.bjorkman@shh.fi
}

and

\section{INSEAD}

SSE/EFI Working Paper Series in Business Administration No. 2000:6

April 2000

The authors would like to thank the Swedish Central Bank and the Finnish Academy for financial support for this project and Antonina Pavlovskaya, Marina Libo, and Natasha Libo for assistance with this project. 


\title{
The Effect of Human Resource Management Practices on MNC Subsidiary \\ Performance in Russia
}

\begin{abstract}
This study investigates the relationship between human resource management (HRM) and the performance of 101 foreign-owned subsidiaries in Russia. The study's results provide support for the assertion that investments in HRM practices can substantially help a firm perform better. Further, different HRM practices for managerial and non-managerial employees are found to be significantly related with firm performance. However, only limited support is obtained for the hypothesized relationship between efforts at aligning HRM practices with firm strategy and subsidiary performance.
\end{abstract}

\section{Key words}

Human resource management

Russia

Performance 


\section{The Effect of Human Resource Management Practices on MNC Subsidiary \\ Performance in Russia}

It is now commonly accepted that employees create an important source of competitive advantage for firms (Barney, 1991; Pfeffer 1994). As a result, it is important that a firm adopts human resource management (HRM) practices that make best use of its employees. The above trend has led to increased interest in the impact of HRM on organizational performance, and a number of studies have found a positive relationship between so called 'high performance work practices' (Huselid, 1995) and different measures of company performance. Furthermore, there is some empirical support for the hypothesis that firms which align their HRM practices with their business strategy will achieve superior outcomes (for recent reviews, see Becker and Gerhart, 1996; Becker and Huselid, 1998; Dyer and Reeves, 1995; and Guest, 1997).

The implications of these findings for multinational corporations, however, remain to be investigated. Most studies of the relationship between HRM and organizational performance have been conducted on the domestic operations of US firms, with a smaller number of studies carried out in Europe (e.g., Guest and Hoque, 1994) and Asia (Ngo et al., 1998). Scholars of international business have so far focused on the extent to which HRM practices within multinational corporations are globally standardized and/or locally adapted (Rosenzweig and Nohria, 1994; Taylor et al., 1996) and largely ignored the relationship between HRM and firm performance (for an exception, see Ngo et al. 1998). Our review of the literature indicates a serious lack of large-sample empirical studies designed to investigate whether extensive use of "high performance" HRM practices and a good alignment between HRM and firm strategy have positive effects on the performance of foreign subsidiaries located in transition economies like China or Russia? To fill some of the above-mentioned voids, this study will examine the relationship between HRM and foreign subsidiary performance in Russia.

The choice of Russia enables us to investigate whether the same positive performance 
effects of HRM practices observed in previous research also hold for Western subsidiaries located in an economy in transition. While business performance of foreign companies in Russia to a large extent depend on external macro factors like general legislation and its frequent change, several authors have pointed to the importance of HRM and provided anecdotal discussions about HRM or discussed one dimension in depth (e.g., Juplev et al., 1998; Laurence and Vlachoutsicos, 1990; Longenecker and Popovski, 1994; May et al; 1998; Magura, 1998; Puffer, 1997; Radko and Afansieva, 1999; Shekshnia, 1994, 1998; Vikhanski and Puffer, 1993; Welsh et al., 1993). Further, individual firms can do little to effect the external environment. This study aims to investigate an important issue which firms can effect. Following the above authors, we argue that such an issue is HRM. In addition, little systematic Russian-language research exists on HRM issues and the field is far from welldeveloped in the Western literature investigating Russian management either. Recent studies such as Elenkov (1997, 1998), Holt et al. (1994), and Ralston et al. (1997) have shown that there are significant differences in the national cultures of Russia and the United States (and Western European countries), and it has been suggested that different HRM practices may be appropriate in Russia than in Western countries (Elenkov, 1998; Juplev et al., 1998). However, this hypotheses has yet to be tested. To the best of our knowledge, ours is the first large-sample study of the relationship between a variety of HRM practices and HRM-strategy alignment, and firm performance in the Russian context.

In addition to contributing to our understanding of the effects of HRM on foreign subsidiary performance in Russia, the current research project may also help us start addressing the wider question of how to manage human resources in subsidiaries located in different environments. This study will also advance the literature by differentiating between HRM practices used for managerial and non-managerial employees. Despite the fact that most firms have different policies for these two groups of employees and a European tradition to study different employee groups, earlier studies on HRM-firm performance have either lumped together HRM practices for different groups of employees or only studied a certain employee category. Including both groups of employees in the same study allows us to 
investigate whether or not same or different HRM practices for managers and non-managerial employees are associated with superior firm performance.

This paper is structured in the following manner. Following this introduction, the next section reviews research on the relationship between HRM and firm performance and HRM in Russia and develops this study's hypotheses. The subsequent sections describe the methodology of the research, present the results, provide a discussion, and finally present conclusions.

\section{THEORETICAL BACKGROUND AND HYPOTHESES}

Recent theoretical work on the resource-based view of the firm (Barney, 1991) supports the notion that HRM may be an important source of competitive advantage. Barney (1991) argued that resources lead to sustainable competitive advantages when they are valuable, rare, inimitable, and non-substitutable. While technology, natural resources, and economies of scale can create value, resource-based theory argues that these sources of value are increasingly available to almost anyone anywhere and they are easy to copy, especially when compared to complex social systems like human resource systems (Ulrich and Lake, 1990). As a result, several authors (e.g., Pfeffer, 1994; Snell et al., 1996; Wright and McMahan, 1992) have contended that human resource systems may be a better source of core competencies which can lead to sustainable competitive advantage. This interpretation is consistent with Hamel and Prahalad (1994, p. 232) who suggest that core competencies are normally people-embodied skills.

As noted by Wright and McMahan (1992), since human performance is normally distributed, human resources meet the first two of Barney's (1991) criteria of being valuable and rare. HRM systems that successfully develop and engage employees to participate in company activities are likely to enhance the value and rareness of a company's human assets (Arthur, 1994; Snell et al., 1996). Further, unlike capital investments or patents, a welldeveloped HR system is an "invisible asset" (Itami, 1987). Human resource strategies are difficult to imitate because of path dependency and causal ambiguity (Barney, 1991; Collis 
and Montgomery, 1995), thus meeting Barney's (1991) third condition.. HRM systems are path dependent since they consist of policies that have evolved over time. A competitor may understand that a particular HRM system is valuable. However, because such systems are unlikely to work the same way if they were removed from the context where they are operating, a competitor cannot simply buy HRM systems in a market. In addition, to copy an HRM system successfully, it is necessary to understand how all relationships inside the system work. Because HRM systems are "invisible assets," it is difficult to develop this needed understanding. Finally, there it is difficult to think of a good substitute for a welldeveloped HRM system, thus HRM systems also meet Bareny's (1991) fourth and final requirement for a resource to be a source of competitive advantage.

The bulk of previous work on the effect of HRM on firm performance has focused on the domestic operations of US firms. However, human assets may be an even more important determinant of the performance of foreign subsidiaries of multinational corporations in countries in transition like Russia since foreign firms often want local employees to change their behavioral patterns and carefully thought-out HRM policies are needed to accomplish this task. As a result, several authors have suggested that human resource management policies are especially critical to a firm's success in Russia (Fey et al., 1999; Longenecker and Popovski, 1994; May et al., 1998; Puffer, 1993, Radko and Afanasieva, 1999; Welsh et al., 1993). Further, compared to Western countries, relatively few employees in Russia are trained in modern market-oriented work practices (Shekshnia, 1994). Recent surveys have indicated that investments in the development of local employees are viewed by foreign executives as important sources of competitive advantage (Shekshnia, 1998; Kravchenko, 1999). Hence, these employees may become an important resource which, due to the scarcity of such human assets, is even harder to duplicate in Russia than in Western countries.

A considerable literature exists on the relationship between individual HRM practices and organizational performance. However, during the last decade, the Personnel/HRM field has shifted from a micro focus on individual HRM practices to a debate on how HRM as a more holistic management approach may contribute to the competitive advantage of the 
organization. The shift from examining single HRM practices to systems of practices entails focusing on the interrelationship between the various elements of the HRM system.

\section{Dimensions of the HRM System}

Becker and Huselid (1998) noted that researchers may either examine the total HRM system or develop and empirically verify through methods such as factor analysis key dimensions of the HRM system. The latter approach assumes that HRM practices group most accurately into several HRM sub-systems and "that to arbitrarily combine multiple [HRM sub-]dimensions into one measure creates unnecessary reliability problems." (Becker and Huselid, 1998, p. 63). This latter approach was followed in this study. Unfortunately, there is little theory specifying precisely how HRM practices should be bundled together (Ngo et al., 1998). Furthermore, most existing work attempting at identifying dimensions of HRM practices has been conducted in studies of domestic firms. Therefore, our approach was to first identify some key HRM dimensions, and then do an exploratory factor analysis to determine precisely which factors exist in data from Russian subsidiaries of Western parent companies.

We took as our starting point the factor structure reported by Ngo et al. (1998) in their study of the relationship between HRM and foreign subsidiary performance in Hong Kong since this study was also done in a developing country. Based on a principal component factor analysis with varimax rotation, Ngo. et al. (1998) obtained two factors with reliability scores of at least 0.64: (1) "structural training and development", and (2) “retention-oriented compensation." HRM policies related to training and development and employee compensation are central in the HRM literature, and similar factors have been reported by several other researchers such as Becker and Huselid (1998, p. 74). However, in an important earlier study Huselid (1995) obtained a slightly different factor structure: one factor that contained items on compensation and promotion [closely related with Ngo et al.'s (1998) compensation factor], and another containing items on employee feedback and skill development. Finally, Delaney and Huselid (1996) divided HRM practices into those that enhance employee skills, practices that help motivate employees, and the way in which the 
workplace is structured. Hence at least the following four HRM dimensions can be identified in previous work: training and development, employee pay system, employee feedback, and workplace organization.

Our exploratory factor analysis on the HRM practices for managerial employees revealed three HRM dimensions: employee development; feedback systems, and pay/organization (reported in Table 1 later in the paper). A separate factor analysis for HRM practices for non-managerial employees led to the same items loading strongest on the same factors, but resulted in somewhat less clean results (higher cross-loadings). These three factors resemble those obtained in previous empirical research and discussed in the theoretical HRM literature. Therefore, the relationship between these three HRM dimensions and their relationship with firm performance was examined in the present study to facilitate comparison between managerial and non-managerial employees. Additionally, as will be discussed below, we hypothesized that efforts at aligning HRM with business strategy would have a positive impact on performance.

\section{Employee Development}

Employee development can be expected to be an important determinant of company performance. A variety of HRM practices are related to the development of the human resources of the firm. First, company investments in both technical and non-technical training are likely to have a positive impact on the extent to which the firm actually succeeds in developing the skills/knowledge of its employees. Training was suggested to be a high performance HRM practice in research by, among others, Delaney and Huselid (1996), Huselid (1995), Koch and McGrath (1996), and MacDuffie (1995). Generally, a positive relationship has been established between employee training and organizational performance (e.g., Delaney and Huselid, 1996; Koch and McGrath, 1996). Delery and Doty (1996) offer an exception.

Employment security is seen by several authors (e.g., Pfeffer, 1995) as an important part of high performance HRM practices. Companies that provide their employees with job security signal a long-standing commitment to their workforce, whom in turn are more 
motivated to develop special skills and competencies that are valued by their company, but perhaps not to the same extent on the external labor market. Employees who perceive that their jobs are secure are also more likely to suggest productivity improvements and to take a more comprehensive and long-term view of their jobs and the company's performance. Conversely, companies are more inclined to take a long-term view on how to develop their employees. In their study on employees in the US banking sector, Delery and Doty (1996) showed a positive relationship between employment security and firm performance.

Companies may use career management programs to assist their employees in career planning. When the company provides this service, one important aim is to identify sequences of job assignments that help employees gain the skills and knowledge viewed as important in the company. A well-functioning company career planning system may also encourage employees to take more responsibility for their own development, including the development of skills viewed as significant in the company (Doyle, 1997). It should be noted that a career planning system not only helps ensure that employees have the skills they need to advance in the company, but also may help ensure that employees possess the mix of skills that the firm believes is important for its future success. In other words, the provision of career planning assistance may have a positive effect on the level and type of skills and knowledge in the company (Doyle, 1997).

Finally companies which promote employees from within the firm are likely to perform well since this feature provides a strong motivation for employees to work hard so that so that they will be promoted (Lepak and Snell, 1999; Pfeffer, 1994). In addition, a philosophy of internal promotion means that a firm has decided to invest in its employees and is thus committed to them. All of the HRM practices listed above can be considered mutually related investments in developing the competencies of the employees. There is no a priori reason to believe that employee development practices would not have a significant positive effect on managers as well as non-managerial employees.

\section{Employee Development in Russia}

Employee development may be of even greater importance in Russia than in Western 
countries (Radko and Afanasieva, 1999; May et al., 1998). Many Russians lack basic business skills due to the historical absence of capitalist-style businesses in Russia, and research on Russia management has revealed that managers viewed training as an important source of competitive advantage (Jukov and Korotov, 1998; Shekshnia, 1998). An interviewbased study of 18 Western firms conducted in 1997-98 also pointed to the importance of competence development in general and training in particular (Fey et al., 1999). This study also reported that “...the most important factor in retaining managerial employees was showing them that the company was committed to Russia and there was room for them to advance in the organization" (Fey et al., 1999, p. 78). Retaining valuable and scarce personnel is a challenging issue that firms in Russia must wrestle with. Thus, commitment to investments in development-oriented HRM practices are likely to improve a firm's ability to retain key human resources. This conclusion indicates that both internal promotions and career management programs should be important in the Russian context. Finally, in a study by Holt et al. (1994), Russian managers, as compared with US managers, placed a higher value on security, and Elenkov (1998) found that Russian managers scored significantly higher on measures of uncertainty avoidance than did US managers. In an economy riddled by high levels of unemployment, it is also likely that non-managerial employees place high value on job security.

In conclusion, HRM practices contributing to development of both Russian managers and other employees can be expected to be positively related to firm performance. As a result of the discussion above, our first hypotheses are:

Hypothesis 1a: A positive relationship exists between the extent a firm develops its managerial employees and firm performance.

Hypothesis 1b: A positive relationship exists between the extent a firm develops its non-managerial employees and firm performance.

\section{Pay/Organization}

Several studies have identified extensive use of teamwork and decentralized decision making as important high-performance HRM practices (Arthur, 1994; MacDuffie, 1995; 
Pfeffer, 1995). Non-hierarchical organizations have a number of potential advantages. Lower-level employees often have more detailed knowledge about organizational issues than do the top executive(s) and can more rapidly and intelligently respond to operational problems. Team-based organizations encourage employees to pool their ideas to come up with creative solutions to problems. Additionally, this organizational form may enhance employee commitment to the organization. This approach is consistent with research that suggests that employee participation can have a statistically significant positive effect on satisfaction and performance at work (Wagner, 1994). Communication across organizational sub-units can be seen as an important ingredient in the functioning of a decentralized organization, because extensive information is needed to integrate operations across sub-units. In the absence of a strong central leadership, this horizontal information flow becomes even more important.

Most studies have included performance-based compensation as one of the high performance HRM practices (e.g. Arthur, 1994; Delery and Doty, 1996; Huselid, 1995; MacDuffie, 1995), and in their study Delery and Doty (1996) identified performance-based compensation as even the single strongest predictor of firm performance. In addition, several different theoretical perspectives have been used to show the effectiveness of performancebased compensation systems including transaction cost theory (Jones and Wright, 1992), control theory (Snell, 1991), and agency theory (Eisenhardt, 1988). Empirical studies on the relationship between performance-related pay and company performance have generally found a positive relationship. Studies on the market reaction to the adoption of incentive plans have also reported positive stock market reactions (see Rajagopalan, 1997). Based on expectancy theory (Vroom 1964), it can be expected that, if the company provides rewards desired by the employee in question, this employee is more likely to perform in a way that will bring him/her the reward. However, of crucial importance is that the performance-based compensation system is in aligned with other parts of the HRM bundle. To the extent that the company extensively uses teamwork and that decision-making is de-centralized, there is a need to reward organizational employees who contribute to a successful implementation of this organizational form. Thus, rewards should not be distributed based on a narrow 
definition of the output of each individual, but also based on appraisals of how well the individual contributes to the performance of the team, the unit, or the company as a whole depending on the company's structure. These objectives might, for instance, be included in the person's performance appraisal.

\section{Pay/Organization in Russia}

While few local Russian companies use pay for performance for their employees (May et al., 1998), Fey et al. (1999) reported that approximately 80 percent of the Western firms in their study used some kind of performance-based compensation system, most typically with bonuses being linked to the performance of the firm. Their experiences with bonus systems were positive, and other scholars have reached the same conclusion (Juplev et al., 1998, Puffer, 1997; Puffer and Shekshina, 1994). Puffer and Shekshina (1994) note that bonus systems are especially helpful in Russia since they help to motivate employees to work towards the company's objectives which are often quite different than objectives local employees have been exposed to previously. Furthermore, field experiment research carried out by Welsh et al. (1993) has shown a strong positive effect of group-based extrinsic rewards on the performance of groups of Russian factory workers.

Research on Russian firms has generally found the relationships between Russian workers and managers to be strained. Russian managers tend to view workers with disdain, and May et al. (1998) report that this attitude towards lower-level employees has not changed a great deal during the 1990s. Puffer et al. (1997) found that Russian managers tend to attach low value to workers participating in decision making. Elenkov (1997) also found that the Russians in his sample scored much higher on Hofstede's (1980) power distance-dimension than did US respondents. In conclusion, the traditional image of Russian leaders as authoritarian holders of unquestioned power who exert micro-controls appears still to hold some validity (Puffer, 1994). Western-owned firms that manage to overcome this tendency towards a top-down work organization may have a valuable competitive advantage in Russia. The peer-based control that goes with a bundle of HRM practices centered around performance-based compensation tied to group/company performance, appraisals, team work, 
decentralization and horizontal communication may also fit well with Russia's collective orientation (Bollinger, 1994; Elenkov, 1997; 1998), and can thus partially replace an extensive management control structure. Teamwork has also been suggested (but not empirically tested) to be a high performance HRM practice in Russia (Magura, 1998). We find the arguments for a proposed relationship between this bundle of HRM practices to be particularly strong for non-managerial employees, but the same line of reasoning can also be used for analyzing the relationship between top executives and middle and junior managers.

Consistent with these arguments, we hypothesize that:

Hypothesis 2a: A positive relationship exists between managerial HRM practices affecting the design of work and a corresponding reward system, and firm performance Hypothesis 2b: A positive relationship exists between non-managerial HRM practices affecting the design of work and a corresponding reward system, and firm performance

\section{Feedback Systems}

Previous research has shown that employees are more motivated when they know what is going on in the firm. Sharing of information on, for example, strategy and company performance conveys to the employees that they are trusted. Further, it is important that employees know what is going on in a firm so that they can use the knowledge that resides in the firm to its fullest potential (Pfeffer, 1998). As a result, it is important that firms use information-sharing programs.

The existence of a well-functioning complaint resolution system may help alleviate situations of perceived injustice or conflicts in the company. Both the process of handling the complaint and the outcome of the process may influence employee perceptions of how firms deal with the situation (Morrison and Robinson, 1997). To the extent that a complaint is properly handled, the employees are more likely to maintain a high level of commitment to the organization. The administration of attitude surveys among the employees may have a similar effect. The use of attitude surveys has also been found beneficial since using such surveys helps top management to understand the desires and ideas of employees. Often employees have good ideas that can help the firm if implemented. In addition, top 
management may learn of small changes in the design of work that can be made and will make many employees much happier and thus more motivated.

\section{Feedback Systems in Russia}

Russian managers have been found to be reluctant to share information, and May et al. (1998, p. 455) report that they have "observed a virtual 'obsession' among some Russian managers to manipulate and control employees." Conversely, Russian employees appear to mistrust their superiors deeply (May et al., 1998; Puffer and McCarthy, 1995). This distrust, however, does not necessarily mean that superior feedback and communication are without importance in Russia. In their research on Russian factory workers, Welsh et al. (1993) found that feedback by superiors on employee functional behaviors and personal praise had positive effects on productivity. Research by Shekshnia (1998) also suggested that there was a positive correlation between the level of employee understanding of organizational strategy and acceptance of organizational culture on the one hand and business results on the other. By sharing information with the employees, top management may help alleviate the feeling of mistrust and suspicion between employees and top managers that has characterized Russian organizations (May et al., 1998). Jukova and Korotov (1998) also suggest (but do not empirically test) that facilitating information sharing inside firms is important in Russia. Together, these studies indicate that bundles of HRM practices that facilitate employee feedback and company information sharing may help foreign-owned firms obtain competitive advantages in Russia.. Such practices are likely to be important for middle and junior managers as well as for other employees. Hence, we arrive at the following hypotheses:

Hypothesis 3a: A positive relationship exists between managerial HRM practices facilitating feedback and firm performance.

Hypothesis 3b: A positive relationship exists between non-managerial HRM practices facilitating feedback and firm performance

\section{HRM-Strategy Alignment}

Scholars have suggested that a good fit between HRM strategies and the business 
strategy of the firm tends to lead to superior outcomes (e.g., Delery and Doty, 1996). In other words, when the company's HRM practices support firm strategy, superior performance is expected. Empirically, the Miles and Snow (1978) or Porter (1980) strategic types have been used to classify firm strategies. Research has provided some support, albeit limited, for a positive HRM-strategy alignment effect.

The relatively weak support for the effects of HRM-strategy alignment on organizational outcomes should come as no surprise as it is difficult to specify what constitutes good alignment in research across firms and industries (Becker and Gerhart, 1996). In fact, the resource-based view (Barney, 1991) suggests that the appropriate configuration and strategic alignment of HRM practices may be idiosyncratic and complex. Furthermore, the whole idea of 'fit' with a certain strategy "seems inappropriate for a world in which there are high levels of dynamic and unpredictable change" (Hiltrop, 1996: 630). Therefore, instead of examining the statistical relationship between HRM practices and measures of firm generic strategies as typically done in previous research, it may be more appropriate to analyze the degree to which companies actively pursue the alignment of strategy and HRM practices (Becker and Huselid, 1998). This approach enables researchers to collect data on the process of alignment, i.e., the extent to which there is an on-going configurational strategic alignment of HRM in an area which is constantly changing (Mabey and Salaman, 1995).

\section{HRM-Strategy Alignment in Russia}

We see no theoretical reason why efforts at aligning HRM with strategy would not have a positive impact on performance also in Russia. However, we have not been able to find any previous research which has investigated this issue. Therefore, the following hypothesis will be tested:

Hypothesis 4. The more effects undertaken to align HRM practices with firm strategy, the better the firm performance. 


\section{METHODOLOGY}

A list of 395 foreign firms operating in Russia was constructed based on lists of Finnish, Swedish, US, German, and British firms operating in Russia. To be part of the list, firms had to be active, have at least 15 employees, have been operating in Russia for at least three years, and be located in Moscow or St. Petersburg. Joint ventures with at least $80 \%$ foreign ownership were treated as foreign firms for this study since in practice it has been found that they tend to be managed as wholly foreign-owned subsidiaries (Makino 1995). Of the 395 firms, only 361 firms could be contacted. Thus, thirty-four firms had either moved to another part of Russia or gone out of business since the list was created.

Contact was made with a human resource manager, general manager, or deputy general manager in each of the remaining 361 firms and the project was explained. Because of considerable fear of anonymous researchers in Russia (likely a result of a desire for secrecy following communism), in most cases a personal meeting was arranged with the manager to further explain the project, learn more about the respondent's firm and HRM practices, and get the questionnaire filled out. In some cases questionnaires were simply left at the firm in person for the manager to complete. Non-respondents were reminded via telephone three times to complete the questionnaire. In cases where the questionnaire had not been received after three telephone calls, additional copies of the questionnaire and a reminder letter were faxed to the respondent, followed by a final follow-up telephone call. This process resulted in 101 responses, representing a $28 \%$ response rate (of the actual number of firms at the point of data collection), which is good for a challenging environment like Russia.

Among the respondents were 38 respondents who were HRM managers and 63 who were general managers or deputy general managers. T-tests were used to investigate the difference between means for the sub-samples of HRM managers and senior managers for the HRM practices and firm performance. Because no significant differences were uncovered, the two subgroups were combined in the analysis that follows. The participating firms were from a variety of foreign countries: 33 from USA, 29 from Sweden, 21 from Finland, 9 from Germany, and 9 from Britain. The participating firms also varied in size with 40 having 15-49 
employees, 17 having 50-99 employees, 12 having 100-199 employees, 22 having 200-999 employees, and 10 having 1000 or more employees.

The questionnaire was pre-tested on a sample of five managers in Russia and slight adjustments were made as a result of their comments. The questionnaire was then translated into Russian using a thorough translation-back translation procedure.

\section{Independent Variables}

Drawing on, among others, the questions in the research instrument used by Huselid (1995), the respondents in the present study were asked the following: "To what extent are each of the following HRM practices used for managers in your firm. Please choose a number between 1 and 5, where 1="to a little extent" and 5="to a great extent"." Similar perceptual scales have been commonly used in studies of HRM practices and organizational performance (e.g. Delery and Doty, 1996; Ngo et al., 1998; Snell and Dean, 1992; Wright et al., 1999). The list of items (see Table 1) contained HRM practices related to employee development, pay/organization, and feedback systems commonly included in previous studies of HRM conducted in the United States, Europe, and elsewhere. Following Becker and Huselid (1998), HRM-strategy alignment was measured through subjective assessment of the degree to which the company analyzes how to align HRM with business strategy.

\section{Dependent Variables}

This study used a performance measure comprised of four five-point subjective managerial assessment questions. Respondents were asked how their firm was performing regarding market share, sales growth, profitability, and quality of products/services where $1=$ poor and 5=outstanding. This measure is desirable since Russian accounting standards are still emerging and firms use different accounting standards which makes it virtually impossible to obtain comparable financial information. While perceptual data may introduce limitations through increased measurement error and the potential for common method bias, the benefits outweigh the risks in this case. Further, there is precedence for using perceptual 
measures of performance in similar research (e.g., Delaney and Huselid, 1996; Youndt et al., 1996). Additionally, prior research has shown that subjective measures of firm performance correlate well with objective measures of firm performance (Geringer and Hebert, 1991; Powell, 1992). Following Roth and O'Donnell (1996), managers at headquarters of 20 of the Russian subsidiaries were also asked to independently evaluate their subsidiaries' performance using the same scale as described above to check how their perceptions correlated with those of the respondents. The measures were significantly correlated at $\Delta=.82$, providing support for asking only subsidiary managers to evaluate performance.

\section{Control Variables}

Data were analyzed using correlation analysis and regression analysis. In the regression analysis, several control variables were also included. The number of years that a foreign corporation has operated in Russia might influence HRM outcomes and firm performance. Companies with more experience in Russia have gone through a learning process concerning how to operate in the Russian context, and a positive relationship may exist between firm experience and HRM outcomes as well as firm performance. Therefore, the age of the subsidiary was included as a control variable. Firm size was also controlled for since larger firms might have more resources to devote to the business. The log of the number of employees in the subsidiary was taken so that a few large firms would not affect the results disproportionately. The home base of the foreign multinational corporation was included as a control variable since several studies have shown that US companies tend to differ from multinational corporations from other Western countries in terms of the HRM practices implemented in overseas settings (for a review, see Ferner, 1997). This variable was measured as a dummy variable (US/non-US parent firm).

Finally, to further control for the potential impact of other factors, we ran separate regression analyses with industry (represented using dummy variables for two-digit SIC codes) and the national cultural distance between Russia and the subsidiary's parent's home 
country [using the index developed by Kogut and Singh (1988), Russian values were taken from Elenkov (1997)]. None of these variables were significant, and thus they were dropped from the regression analyses reported in this article to preserve degrees of freedom.

\section{RESULTS}

The first step in our analysis was to conduct a principal component factor analysis with varimax rotation on the individual HRM management practice items (see Table 1). The HRM managerial employee practice items factored into three factors with low cross loadings. The first factor (bundle of HRM practices) which we label "development" is comprised of technical

------- Insert Tables 1 and 2 about here

training, non-technical training, non-entry level jobs filled from within the firm, assistance provided for career planning, and job security. The second factor "feedback" is comprised of information sharing programs, complaint resolution system, and attitude surveys. The final factor "pay/organization" is made up of performance appraisals, group/company performance in pay, teamwork, decentralized decision making, and interdepartmental communication. The indexes all had Cronbach's Alphas above .675, close to the suggested reliability level of .70 (Nunnally, 1978). A separate factor analysis for HRM practices for non-managerial employees led to the same items loading strongest on the same factors, but resulted in somewhat less clean results (higher cross-loadings). Cronbach's Alphas for the employee HRM factors were all over 650 .

Table 2 provides the means, standard deviations, and bivariate Pearson correlations for the main variables used in the regression equations. Consistent with much prior research on the relationship between HRM practices and firm performance, all six correlations between the bundles of HRM practices for managers and non-managerial employees, and firm performance are positive and statistically significant. Also, HRM-strategy alignment was positively correlated with firm performance (at $\mathrm{p}<.05$ ). This provides some preliminary support for all our hypotheses. However, a more refined analysis to test these hypotheses 
will follow. Particularly high correlations (.72 and higher) exited between each of the bundles of HRM practices for managers and their corresponding HRM practice bundles for nonmanagerial employees. Therefore, we addressed this potential problem in our analysis by running separate analyses for the two employee groups ${ }^{2}$. It is also encouraging that the order (in terms of size) that the HRM boundles are correlated with firm performance is consistent with the order (in terms of size) of the betas in the regression equations.

Insert Table 3 about here

Regression analysis was used to test our specific hypotheses. Model 1 in Table 3 shows the results of the regression analysis for the HRM practices for subsidiary managers. The model was highly significant, with an $\mathrm{R}^{2}$ of .339 and an adjusted $\mathrm{R}^{2}$ of .287 . Management development and managerial feedback systems as well as HRM-strategy alignment were significantly related with firm performance, providing further support for hypotheses 1A, 3A, and 4. However, there was no significant relationship between pay/organization and organizational performance. Of the control variables, firm size was significantly related with firm performance indicating that larger firms slightly outperformed smaller firms in our sample.

Model 2 shown in Table 3 reports the analysis of the data on non-managerial employees. Also this model was highly significant, $\mathrm{R}^{2}$ being .379 and adjusted $\mathrm{R}^{2} .330$. Whereas the results support hypotheses 1B (employee development) and 2B (pay/organization), no statistically significant relationship was found between employee feedback or HRM-strategy alignment and firm performance. Firm size was again significantly related with firm performance. Employee Pay/Organization had by far the largest beta (standardized regression coefficient) indicating that it had the largest effect on firm performance.

In conclusion, consistent support was obtained for hypotheses 1A (management development), 1B (employee development), 2B (pay/organization for non-managerial employees), and 3A (feedback to managerial employees). Like much previous research, our results provide mixed support for the importance of alignment of HRM with strategy. Thus, only partial support is provided for hypothesis 4 . 


\section{DISCUSSION AND CONCLUSION}

The results of this study provide relatively strong support for the existence of a positive relationship between HRM practices and the performance of Russian subsidiaries of Western corporations. At a general level, this result is largely consistent with results obtained in studies of HRM-firm performance conduced in other geographical settings (Becker and Gerhart, 1996; Guest, 1997; Becker and Huselid, 1998). A contribution of the present study is corroborating these results in the context of foreign subsidiaries of Western multinational companies located in a country in transition.

However, the relationship between the use of HRM practices and firm performance did not hold across the three bundles of HRM practices (employee development; feedback systems, and pay/organization) for managers and non-managerial employees studied in the present study. While a strong positive relationship was found between both management development and employee development, and firm performance, a decentralized and teambased organization with corresponding pay systems was positively related with firm performance only for non-managerial employees; the opposite was found for the relationship between feedback and firm performance. It is well-known that firms tend to use different HRM practices for these two groups of employees, yet surprisingly most previous studies on HRM-firm performance have asked questions about HRM practices for the firm as a whole or only focused on one particular employee group. This study suggests that, at least in the Russian context, firms should focus on different bundles of HRM practices for managerial and non-managerial employees. One of the conclusions of our study is that future studies should follow our lead and collect separate data for different employee groups despite the additional challenges this causes.

Both management and employee development were significantly related with firm performance. Due to Russia's transformation from a communist to a capitalist society, most Russian managers have limited traditional management training and little experience in many areas of business. At the same time, Russian managers tend to be highly educated in some other area--often with a Ph.D. in science/engineering due to the Soviet Era's focus on these 
disciplines. In fact, Soviet society highly valued education and this tradition remains an important value for most Russian people today. Given the educational/experience gaps and interest in business education that most Russians have (Shekshnia, 1998; Fey et al., 1999), it is not surprising that Russian managers and hence their firms benefit from various training initiatives. Also non-managerial employee development was important for firm performance. Again, this can be expected. A focus on employee development, including employment security, is likely to be reciprocated by employees in terms of high levels of organizational commitment. Investments in employee training may also be important for Western firms striving to achieve a competitive advantage through high-quality products and services, features that were not paid much attention to during the earlier planned economy. Future comparative research on other economies in transition is needed in order to establish the generalizability of these findings.

Several studies have identified extensive use of teamwork and decentralized decision making as important high performance HRM practices, especially in combination with reward systems linked with group performance (Arthur, 1994; MacDuffie, 1995; Pfeffer, 1995). In our study we found only a positive relationship between this HRM dimension and firm performance for non-managerial employees. We can only speculate why there was no positive relationship between this HRM factor for managers and firm performance. During the communist regime personal initiatives were not only discouraged, but were even punished (Puffer, 1993). The hierarchical nature of the Russian society may also discourage individual responsibility taking and initiatives on the part of middle managers (Elenkov, 1998), something that Western expatriates have viewed as a common problem in Russia (May, et al., 1998). It could be that while a focus on collective responsibility and group-based bonuses works well for non-managerial employees, firms need to focus more on individual responsibility taking and rewards based on individual performance for managers. More research is obviously needed on this point, both in Russia and on the operations of Western subsidiaries located in other transition economies.

While we found that implementing HRM practices which facilitate Russian managers providing feedback to top management and obtaining more information about what is going 
on in the firm was highly significantly related to firm performance, having such HRM practices for non-managerial employees had little effect on firm performance. One possible explanation is related to the high power distance found among Russians (Elenkov, 1997). Many Russian top managers share little information with their colleagues (May et al., 1998), and middle and junior managers may not have the information they need to do their jobs efficiently. Conversely, the opinions of lower-level managers may not be encouraged and known by Russian top managers. Firms with extensive flows of information between top management and managerial employees may thus have a competitive advantage in Russia. In contrast, non-managerial employees may neither expect an extensive information flow between them and the leadership of the firm, nor may top-down information be as important for their jobs as for the middle and junior managers. More research on this issue is needed to unravel factors helping us to explain these results. Of interest would also be to collect longitudinal data on the impact of feedback for non-managerial employees on firm performance. A plausible hypothesis would be that over time its importance as a determinant of firm performance will decrease for managerial employees as more foreign firms increase the information flow between top management and middle and junior management (leading to a loss of competitive advantage for firms already doing it), while feedback will become more important for non-managerial employees. Further, research in other geographical settings is also clearly warranted to see how generalizeable/divergent results are. For instance, it would be of interest to do comparative analyses of the relationship between employee feedback and firm performance in other high power distance countries as well as in low power distance countries.

Several implications for managers clearly flow out of this article. First, investing in using HRM practices results in firms performing better. Second, it is optimal for a firm to have different HRM practices for managerial and non-managerial employees. Third, not all HRM practices are equally important to focus on. Specifically, management and employee development, feedback and information systems for managers, and extensive use of teamwork and decentralized decision making combined with reward systems based on group performance for non-managerial employees have positive effects on firm performance. As a 
result, the above HRM practices are the most important HRM boundles which foreign firms operating in Russia should focus their efforts on.

There has been considerable debate in the HRM literature about the importance of aligning HRM practices with firm strategy. Our results are in line with most previous research (Becker and Huselid, 1998) in that they provide only limited support for the hypothesized positive relationship between efforts at aligning HRM practices with firm strategy and firm performance. Future work would benefit from analyzing both the efforts at aligning HRM practices and strategy (investigated in this study) and the outcome of these efforts. Case studies would probably be the best methodological choice for investigating the interaction between HRM systems and firm strategy and how this relationship impacts on performance.

Like all research, the present study has several limitations. Our paper begins to explore the question of causality. However, causality can actually be tested only with data collected at different points in time. For instance, while we in this paper have argued that HRM tends to be a driver of firm performance, previous research has also shown that increasing profits tend to lead to higher investments in training (Hendry et al., 1989). Thus, the field would greatly benefit from more time-series studies that can better address causality (Becker and Huselid, 1998). Future research could also benefit from developing more sophisticated measures of firm strategy to assist in investigating the importance of HRM practices being aligned with firm strategy in order for a firm to achieve maximum performance. Similar to many previous studies in this field, data on HRM practices were collected through perceptual scales. Another possibility would be to use more specific and behavioral scales (Becker and Huselid, 1998) which would be more difficult to get respondents to provide, but might be more accurate. It would also be useful in future studies to collect performance data from other respondents to minimize the risk of common method bias. While this study makes important contributions to our understanding of the relationship between HRM and foreign subsidiary performance in general and in Russia in particular, this study is clearly only a first step and additional research is needed on this issue both in Russia and in other geographical settings. 


\section{ENDNOTES}

1. Mabey and Salaman (1995) point out that firms should base performance-related compensation systems on meaningful goals, robust performance measures, significant rewards, and wellestablished links between performance and rewards in order to obtain positive performance effects. In the present study we will not investigate the details of the compensation system. It should also be noted that some scholars are more skeptical of the effects of performance-related pay (e.g., Roberts, 1997).

2. Correlations between the three HRM dimensions (for either managers or non-managers) also indicate that they are unlikely to be totally independent. Therefore, if entered simultaneously into a regression equation, multicolinearity could be a problem. However, as results were consistent when running the full models (including control variables, HRM bundles for either managers or non-managers, and HRM-strategy alignment) as compared with running separate models for each of the HRM bundles, we only report the full models containing either all three managerial HRM boundles or all three non-managerial HRM boundles.

\section{REFERENCES}

Arthur, Jeffrey B. 1994. Effects of human resource systems on manufacturing performance and turnover. Academy of Management Journal, 37: 670-687.

Barney, Jay B. 1991. Firm resources and sustained competitive advantage. Journal of Management, 17: 99-120.

Becker, Brian \& Barry Gerhart. 1996. The impact of human resource management on organizational performance: Progress and prospects. Academy of Management

Journal, 39: 779-801.

Becker, Brian \& Mark A. Huselid.1998. High performance work systems and firm performance: A synthesis of research and managerial implications. Research in Personnel and Human Resource Management, 16: 53-101.

Bollinger, Daniel 1994. The four cornerstones and three pillars in the house of Russia management system. Journal of Management Development, 13(2): 49-54.

Collins, David J. \& Cynthia A. Montgomery. 1995. Competing on resources: Strategy for the 1990s. Harvard Business Review, 73(4): 118-128.

Delaney, John T. \& Mark A. Huselid. 1996. The impact of human resource management on perceptions of organizational performance. Academy of Management Journal, 39: 949-969.

Delery, John E. \& Harold Doty. 1996. Models of theorizing in strategic human resource management: tests of universalistic, contingency, and configurational performance predictions. Academy of Management Journal, 39: 802-835.

Doyle, M. 1997. Management development. In Ian Beardwell \& Len Holden (Eds.), Human resource management -- A contemporary perspective. London: Pitman. 
Dyer, Lee \& Todd Reves. 1995. Human resource strategies and firm performance: What do we know and where do we need to go? The International Journal of Human Resource Management, 6(3): 656-670.

Eisenhardt, Kathleen 1988. Agency and institutional-theory explanations: The case of retail sales compensation. Academy of Management Journal, 31: 488-511.

Elenkov, Detelin S. 1998. Can American management concepts work in Russia: A crosscultural comparative study. California Management Review, 40(4): 133-156.

Elenkov, Detelin S. 1997. Differences and similarities in managerial values between US and Russian managers. International Studies of Management and Organization, 28(1): 85-106.

Ferner, Anthony. 1997. Country of origin effects and HRM in multinational companies. Human Resource Management Journal, 7: 19-37.

Fey, Carl F., Pontus Engström, \& Ingmar Björkman. 1999. Effective human resource management practices for foreign firms in Russia. Organizational Dynamics, Autumn: 69-80.

Geringer, Michael J. \& Loius Hebert. 1991. Measuring performance of international joint ventures. Journal of International Business Studies, 28: 249-263.

Guest, David E. 1997. Human resource management and performance: A review and research agenda. International Journal of Human Resource Management, 8: 263-276.

Guest, David E. \& Kim Hoque. 1994. The good, the bad, and the ugly: Employment relations in new non-union workplaces. Human Resource Management Journal, 5: 1-14.

Hamel, Gary \& C.K. Prahalad. 1994. Competing for the future. Harvard Business Review, 72: $122-128$.

Hendry, Chris, Andrew Pettigrew, \& Paul Sparrow. 1989. Linking strategic change, competitive performance, and human resource management: Results of a UK empirical study. In R. Mansfield (Ed.), Frontiers of management. London: Routledge.

Hofstede, Geert. 1980. Culture's consequences: International differences in work-related values. Newbury park, CA: Sage.

Holt, David H., David A. Ralston, \& Robert H. Terpstra. 1994. Constraints on capitalism in Russia: The managerial Psyche. California Management Review, 36(3): 124-136.

Huselid, Mark A. 1995. The impact of human resource management practices on turnover, productivity, and corporate financial performance. Academy of Management Journal, 38: 635-672.

Itami, H. 1997. Mobilizing invisible assets. Boston: Harvard University Press.

Jones, G. \& Patrick. Wright. 1992. An economic approach to conceptualizing the utility of human resource management practices. In K. Rowland \& G. Ferris (Eds.) Research in personnel and human resource management, 10: 271-300. Greenwich, CT: JAI.

Jukova, Margarita \& Konstantin Korotov. 1998. From a personnel department in Soviet Union to a human resource department in Russia. People and Labor, 8: 88-91. (in Russian). 
Juplev, A.V., A.G. Konkov, \& V.F. Kisner. 1998. Motivation and problems of small enterprise: The experience of Russia and USA. Human Resource Management, 8: 44-53. (in Russian).

Koch, Marianne J. \& Rita G. McGrath. 1996. Improving labor productivity: Human resource management policies do matter. Strategic Management Journal, 17: 335-354.

Laurence, Paul R. \& Charalambos A. Vlachoutsicos. 1990. Behind Factory Walls: Decision making in Soviet and US enterprises. Boston, MA: Harvard Business School Press.

Lepak, David P. \& Scott A. Snell. 1999. The human resource architecture: Towards a theory of human captial allocation and development. Academy of Management Review, 24(1): 3148.

Longenecker, Clinto O. \& Serguei Popovski. 1994. Managerial trials of privatization: Retooling Russian managers. Business Horizons, 37(6): 35-43.

Mabey, Christopher \& Graeme Salaman. 1995. Strategic Human Resource Management. Oxford: Basil Blackwell.

MacDuffie, John P. 1995. Human resource bundles and manufacturing performance: Flexible production systems in the world auto industry. Industrial Relations \& Labor Review, 48: 197221.

Magura, Mikhael I. 1998. Patriotism of personnel and their relation to the organization--a firm's major competitive advantage. Human Resource Management, 11: 20-28. (In Russian).

Makino, Shige 1995. Joint venture structure and performance: Japanese joint ventures in Asia. Unpublished Ph.D. Dissertation, University of Western Ontario, Canada.

May, Ruth, Carol B. Young, \& Donna Ledgerwood. 1998. Lessons from Russian human resource management experience. European Management Journal, 16(4): 447-459.

Miles, Raymond E. \& Charles C. Snow. 1978. Organizational strategy, structure, and process. New York: McGraw Hill.

Morrison, Elizabeth W. \& Sandra L. Robinson. 1997. When employees feel betrayed: A model of how psychological contract violations develop. Academy of Management Review, 22: 226-256.

Ngo, Hang-Yue, Daniel Turban, Chung-Ming Lau, and Siu-yun Lui. 1998. Human resource practices and firm performance of multinational corporations: Influences of

country of origin. Journal of International Human Resource Management, 9: 632-652.

Nunnally, Jeffrey. 1978. Psychometric theory. New York: McGraw Hill.

Pfeffer, Jeffrey. 1994. Competitive advantage through people: Unleashing the power of the work force. Boston: Harvard Business Press.

Pfeffer, Jeffrey. 1995. Producing sustainable competitive advantage through the effective management of people. Academy of Management Executive, 9: 55-69.

Pfeffer, Jeffrey. 1998. The human equation: Building profits by putting people first. Boston: Harvard Business Press. 
Porter, Michael E. 1980. Competitive strategy. New York: The Free Press.

Powell, Thomas C. 1992. Organizational alignment as a competitive advantage. Strategic Management Journal, 13: 551-558.

Puffer, Sheila M. 1993. A riddle wrapped in an enigma: Demystifying Russian managerial motivation. European Management Journal, 11: 473-480.

Puffer, Sheila M. 1997. Soviet and American managers' reward allocations: A dependency approach. International Business Review, 6: 453-476.

Puffer, Sheila M. \& Daniel J. McCarthy. 1995. Finding the common ground in Russian and American business ethics. California Management Review, (Winter): 29-46.

Puffer, Sheila M., Daniel J. McCarthy, \& Alexander I. Naumov. 1997. Russian managers' beliefs about work: Beyond the stereotypes. Journal of World Business, 32: 258-276.

Puffer, Sheila M. and Stanislav V. Shekshnia. 1994. Compensating local employees in postcommunist Russia: In search of talent or just looking for a bargin? Compensation \& Benefits Review, (September-October): 1-9.

Radko, S. \& A. Afanasieva. 1999. Conservation of labor potential and maximization of income. People and Labor, 7: 81-85. (in Russian).

Rajagopalan, Nandimi. 1997. Strategic orientations, incentive plan adoptions, and firm performance: Evidence from electric utility firms. Strategic Management Journal, 18: 761785.

Ralston, David A., David H. Holt, Robert H. Terpstra, \& Y. Kai-Cheng. 1997. The impact of national culture and economic ideology on managerial work values: A study of the united states, Russia, Japan, and China. Journal of International Business Studies, 28: 177-207.

Rosenzweig, Philip M. \& Nitin Nohria. 1994. Influences of human resource management practices in multinational corporation. Journal of International Business Studies, 25: 229251.

Roth, Kendall \& Sharon O'Donnell. 1996. Foreign subsidiary compensation strategy: An agency theory perspective. Academy of Management Journal, 39: 678-703.

Shekshnia, Stanaslav. 1994. Managing people in Russia: Challenges for foreign investors. European Management Journal, 12: 298-305.

Shekshnia, Stanaslav. 1998. Western multinationals' human resource practices in Russia. European Management Journal, 16: 460-465.

Snell, Scott A. 1991. Executive use of human resource management controls to improve firm performance: Modeling effect of administrative information. Academy of Management Best Papers Proceedings: 277-281.

Snell, Scott A. and J. Dean. 1992. Integrated manufacturing and human resource management: A human capital perspective. Academy of Management Journal, 35: 467-504.

Snell, Scott A., Mark A. Youndt, and Patrick M. Wright. 1996. Establishing a framework for research in strategic human resource management: Merging resource theory and 
organizational learning. Research in Personnel and Human Resource Management, 14: 6190 .

Taylor, Sully, Schon Beechler, \& Nancy Napier. 1996. Towards a model of strategic international human resource management. Academy of Management Review, 21: 959-986.

Ulrich, Dave \& D. Lake. 1990. Organizational capability: Competing from the inside out. New York: Wiley.

Vikhanski, Oleg \& Sheila M. Puffer. 1993. Management education and employee training at Moscow McDonalds. European Management Journal, 11: 102-107.

Vroom, Victor. 1964. Work and motivation. New York: Wiley.

Wagner, John A. 1994. Participation's effect on performance and satisfaction: A reconsideration of research evidence. Academy of Management Review, 19: 312-331.

Welsh, Dianne H. B., Fred Luthans, \& Steven M. Sommer. 1993. Managing Russian factory workers: The impact of US-based behavioral and participative techniques. Academy of Management Journal, 36: 58-79.

Wright, Patrick M. \& Gary C. McMahan. 1992. Theoretical perspectives for strategic human resource management. Journal of Management, 18: 295-320.

Wright Patrick M., Blaine McCormick, Scott Sherman, \& Gary C. McMahan. 1999. The role of human resource practices in petro-chemical refinery performance. International Journal of Human Resource Management, 10: 551-571

Youndt, Mark A., Scott A. Snell, James W. Dean, \& David P. Lepak. 1996. Human resource management, manufacturing strategy, and firm performance. Academy of Management Journal, 39: 836-866. 
Table 1: Rotated Component Matrix

$\begin{array}{cccc}\text { Variable } & \begin{array}{c}\text { Factor 1 } \\ \text { Development }\end{array} & \begin{array}{c}\text { Factor 2 } \\ \text { Feedback }\end{array} & \begin{array}{c}\text { Factor 3 } \\ \text { Pay/ } \\ \text { organization }\end{array} \\ \begin{array}{c}\text { Technical training } \\ \text { Non-technical training }\end{array} & \mathbf{. 5 6 1} & .339 & .008 \\ \text { Non-entry jobs filled from within firm } & . \mathbf{6 0 7} & .287 & .287 \\ \text { Assisting in career planning } & . \mathbf{6 0 1} & .104 & .297 \\ \text { Job security } & .634 & .331 & .008 \\ \text { Information sharing programs } & .748 & -.222 & .140 \\ \text { Complaint resolution system } & -.007 & .636 & .230 \\ \text { Attitude surveys } & .236 & .621 & .002 \\ \text { Performance appraisals } & .180 & .790 & .125 \\ \text { Group/company performance in pay } & .252 & .116 & . \mathbf{5 3 1} \\ \text { Teamwork } & .006 & -.009 & . \mathbf{8 7 2} \\ \text { Decentralized decision making } & .335 & .364 & . \mathbf{5 6 5} \\ \text { Interdepartmental communication } & .274 & .197 & . \mathbf{4 5 6} \\ \text { Eigenvalue } & .149 & .354 & .616 \\ \text { \% variance explained } & 2.53 & 2.22 & 2.15 \\ \text { Alpha } & 19.44 & 17.08 & 16.5 \\ & .737 & .677 & .718\end{array}$


Table 2: Correlations

$\begin{array}{lllllllllll}\text { Variables } & 1 & 2 & 3 & 4 & 5 & 6 & 7 & 8 & 9 & 10 \\ \text { 1. PERFORMANCE } & & & & & & & & & & \\ \text { 2. Manager Development } & .476^{* *} & & & & & & & & & \\ \text { 3. Man. Pay/Organization } & .289^{* *} & .450^{* *} & & & & & & & & \\ \text { 4. Manager Feeback } & .403^{* *} & .581^{* *} & .421^{* *} & & & & & & & \\ \text { 5. Employee Development } & .443^{* *} & .775^{*} & .525^{* *} & .519^{* *} & & & & & & \\ \text { 6. Employee Pay/Organization } & .535^{* *} & .420^{* *} & .723^{* *} & .503^{* *} & .480^{* *} & & & & & \\ \text { 7. Employee Feedback } & .321^{* *} & .494^{* *} & .511^{* *} & .725^{* *} & .682^{* *} & .518^{* *} & & & & \\ \text { 8. HRM-Strategy Fit } & .269^{*} & .204^{*} & .220^{*} & .071 & .265^{* *} & .328^{* *} & .138^{* *} & & & \\ \text { 9. \# Years Firm in Russia } & .166 & .175 & .331^{* *} & .205^{*} & .157 & .232^{*} & .115^{*} & .030 & & \\ \text { 10. Log of \# Employees } & .330^{* *} & .360^{* *} & .332^{* *} & .147 & .260^{*} & .303^{* *} & .109 & .068 & -.025 & \\ \text { 11. US Parent } & .187 & .077 & -.042 & -.041 & .062 & .121 & .064 & .050 & -.071 & .042 \\ \text { Mean } & \mathbf{2 . 6 2} & \mathbf{3 . 2 6} & \mathbf{2 . 7 7} & \mathbf{3 . 9 2} & \mathbf{3 . 1 5} & \mathbf{2 . 0 1} & \mathbf{3 . 1 7} & \mathbf{2 . 6 3} & \mathbf{1 2 . 2 0} & \mathbf{1 . 3 3} \\ \text { S.D. } & \mathbf{0 . 7 8} & \mathbf{0 . 9 5} & \mathbf{1 . 0 6} & \mathbf{1 . 1 0} & \mathbf{0 . 9 2} & \mathbf{1 . 0 1} & \mathbf{0 . 9 0} & \mathbf{1 . 3 0} & \mathbf{9 . 2 3} & \mathbf{0 . 4 7}\end{array}$

$* \mathrm{p}<.05, * * \mathrm{p}<.01, * * * \mathrm{p}<.005, * * * * \mathrm{p}<.001$ 
Table $3^{\text {a,b.c }}$ : Regressions on Firm Performance

$\begin{array}{lll}\text { Independent Variables } & \text { Model 1 } & \text { Model } 2 \\ \text { Log of number of employees } & .222^{*} & .163^{*} \\ \text { Age of firm in years } & .113 & .064 \\ \text { US/Non-US } & .144 & .124 \\ \text { HRM-Strategy fit } & .192^{*} & .069 \\ \text { Employee development } & & .245^{*} \\ \text { Employee pay/organization } & & .352^{* * * *} \\ \text { Feedback to employees } & & .073 \\ \text { Manager development } & .221^{*} & \\ \text { Manager pay/organization } & -.040 & \\ \text { Feedback to managers } & .201^{*} & \\ \text { R } & & .379 \\ \text { Adjusted R } & .339 \\ \text { F } & .287 & .330 \\ \text { N } & 6.519^{* * * *} \\ \text { a Dependent variable= firm performance } & 7.768^{* * * *} \\ \text { b. Standardized regression coefficients are shown. } \\ \text { c. *p<.05, **p<.01, ***p<.005, ****p<.001 }\end{array}$

